\title{
The Development of Japanese History Teaching Materials With ADDIE Method
}

\author{
Alpina Pamugari ${ }^{1 *}$, Yosefa Putri Tanjungsari ${ }^{2}$, Ari Artadi $^{3}$, Hari Setiawan ${ }^{4}$ \\ Department of Japanese Language and Culture, Darma Persada University, Jakarta, Indonesia \\ *Email: pamugari.alpina@gmail.com
}

\begin{abstract}
Japanese history course is one of the primary supporting knowledge for Japanese language and culture learners to understand Japan as a whole. Therefore, the Japanese Language and Culture department at Darma Persada University, providing a Nihon no Rekishi (Japan History) lecture using Japanese language textbooks of Japan History. However, based on the results of the evaluation using a questionnaire, Japanese language modules that our campus had now does not give a positive impact on student understanding. Based on this, our goal is to make Japanese History module with developing lecture materials. The development of teaching materials in the form of this module is a Research and Development $(R \& D)$ research, based on the ADDIE (Analyse, Design, Development, Implementation, Evaluation) method. First, the results of the analyse phase is improvement needed in order to be able to present knowledge that is not only useful and actual but also encourages students to think critically about Japan history. Second, the results at the design stage, a teaching module is prepared, which contains balanced explanations with pictures or mini videos. They can question about pictures or figures or events that have multiple perspectives for discussed with teacher in lectures. Third, in the development stage, based on the results of analysing and design stages with consultations from leading universities in Japan experts found that at the development stage, have the results that the implementation and evaluation contents of the module are a simplification of reference literature materials, and provide several perspectives on figures and events in Japanese history.
\end{abstract}

Keywords: Japanese History; ADDIE method; modules

\section{Introduction}

Japan is one of the developed countries in East Asia. The progress of Japan that we can see today is a long result of the country's development through a process that is not instantaneous. Japanese history has continuity between one event and another so that the Japanese history is based more on historical events concerning the emergence or end of a regime, the entry of a new cultural influence, political system, religion, or thought.

History education includes lessons of moral education, which has the purpose of nurturing people to be wise man, statesman to be skilled and citizens to think smart and useful, have critical thinking skills, and save memory \& imagination (Kochhar, 2008). Wineburg (2006) explains that history has the potential to make us human beings. Other subjects in the school curriculum cannot do these things.

Research about Japanese history teaching method throughout the university in Indonesia, especially at faculty of Japanese studies in the form of scientific articles contained in journals has not been conducted. Based on research conducted by TEA Online Curriculum Projects, College of Arts and Sciences, University of Colorado Boulder, they successfully made an online curriculum named Imaging Japanese History. It is an online curriculum designed to enhance students' visual literacy skills, historical thinking skills, and knowledge of Japanese history. Five online modules each provide a case study in the role of art in capturing and conveying the human experience: 1) A Case Study of Heian Japan 
through Art: Japan's Four Great Emaki; 2) A Case Study of Medieval Japan through Art: Samurai Life in Medieval Japan; 3) A Case Study of Tokugawa Japan through Art: Views of a Society in Transformation; 4) Becoming Modern: Early 20th Century Japan through Primary Sources; 5) A Case Study of Late Twentieth-Century Japan through Art: Tezuka Osamu and Astro Boy.

The modules address essential content from the National Standards for World History. They are designed to help students answer the following essential questions about Japan during particular periods in its long history: a). What did it mean to be Japanese? How did art reflect and record the lives, thoughts, and conditions in which the Japanese lived at particular moments in time? b). How can art be read to uncover Japanese cultural values, belief systems, social structures, and identities at particular times? c). How do Japanese arts reflect unity and diversity in Japanese society across periods of Japanese history?

Each module contains the following components: a). An introductory essay on the social history of the period, written by a leading scholar of that period. Introductory essays provide teachers with the background needed to understand the questions that historians have asked about this period and how the understanding of the period has changed with new scholarship. Designed primarily as teacher background, the essays also may be assigned to students in lieu of the textbook treatment of the period; b). A two- to a three-day lesson that engages students in "reading" artwork and visual materials as primary historical sources to understand a historical period better. Students will consider how the art reflects the period in which it was created-for example, how it incorporated aesthetics, cultural trends, foreign influences, religious ideals, and social trends. In essence, the art will serve as a "case study" of the period.
The research above actually was designed for high school student in the US, but it could be a reference for developing teaching materials of Japanese history in university. Studying history at a university level involves more than memorising established historical facts and theories. The main point of higher education is to teach the students how to use historical sources - that is, private and public documents and records created by people of the past. Besides, it also to reconstruct the period being studied through interpretation and analysis of those documents and to perceive historical events as interconnected segments in the chain of time.

According to Gomi (2017), the history of Japan is broadly divided into 4, namely 原始 - 古代 genshi-kodai (ancient/prehistoric times), 中世 $\mathrm{ch} \bar{u}$ sei (medieval), 近世 kinsei (early modern times), 近代 - 現代 kindai-gendai (modern/contemporary). From this period, it is further divided into per epoch, as shown in the table of the history of Japan in table 1 . The change of time marks a massive change and raises questions such as: what was the background of the change of time.

As teaching material, we compile some source. (Nishiumi, 2007) highlight turning points in Japanese history, and while discussing this history, it explains the most significant events. Furthermore, it compares Japanese history with Western history and to arrange the logic itself in a way that is easy for them to understand.

In studying Japanese history, the relationship between Japan and other countries also needs to be observed, so that the Nihon no Rekishi course is not only focused on Japanese history alone. As Japanese language learners in Indonesia, Darma Persada University students need to understand the historical relationship between Japan and Indonesia as well. 


\begin{tabular}{|c|c|c|c|c|c|}
\hline \multicolumn{6}{|c|}{$\begin{array}{c}\text { Table } 1 \\
\text { Japan Historical Periode }\end{array}$} \\
\hline Year & Division & Era & Sovereign & $\begin{array}{l}\text { Social Sys- } \\
\text { tem }\end{array}$ & Remarks \\
\hline $\begin{array}{l}\text { Before } \\
250 \mathrm{M}\end{array}$ & Prehistoric & $\begin{array}{l}\text { Paleolitikum, } \\
\text { Jomon, Yayoi }\end{array}$ & - & Community & $\begin{array}{l}\text { Only blood relationships make up or- } \\
\text { ganisations \& communities. }\end{array}$ \\
\hline $250-1185$ & Ancient & $\begin{array}{l}\text { Kofun, Asuka, } \\
\text { Nara, Heian }\end{array}$ & Emperor & $\begin{array}{l}\text { Ryosen sys- } \\
\text { tem }\end{array}$ & $\begin{array}{l}\text { Society is divided into three groups or } \\
\text { castes: jinmin, ryoumin, and senmin }\end{array}$ \\
\hline $\begin{array}{l}1185- \\
1573\end{array}$ & $\begin{array}{l}\text { Medieval } \\
\text { (Middle age) }\end{array}$ & $\begin{array}{l}\text { Kamakura, } \\
\text { Muromachi }\end{array}$ & Samurai & Feudalism & $\begin{array}{l}\text { Sengoku jidai (Warring States Period) } \\
\text { with retainer supplanting the lord }\end{array}$ \\
\hline $\begin{array}{l}1573- \\
1868\end{array}$ & $\begin{array}{l}\text { Pre-Modern } \\
\text { (Early modern) }\end{array}$ & $\begin{array}{l}\text { Azuchi } \\
\text { Momoyama, } \\
\text { Edo }\end{array}$ & Samurai & Feudalism & $\begin{array}{l}\text { Bakuhan Taisei (Shogunate system) } \\
\text { after Japan unification. Sakoku (except } \\
\text { Netherland, China, Korea) }\end{array}$ \\
\hline $\begin{array}{l}1868- \\
1945\end{array}$ & Modern & $\begin{array}{l}\text { Meiji, Taisho, } \\
\text { Showa }\end{array}$ & Emperor & Capitalism & $\begin{array}{l}\text { Modern state development, light } \& \\
\text { heavy industry, militarism }\end{array}$ \\
\hline 1945-now & Contemporary & After WW II & Citizen & Capitalism & $\begin{array}{l}\text { Postwar reformation by GHQ, an eco- } \\
\text { nomic superpower, pacifism, Contra- } \\
\text { diction between the constitution and } \\
\text { US-Japan Security }\end{array}$ \\
\hline
\end{tabular}

Source: https://langsquare.exblog.jp/20844310/ with English translation

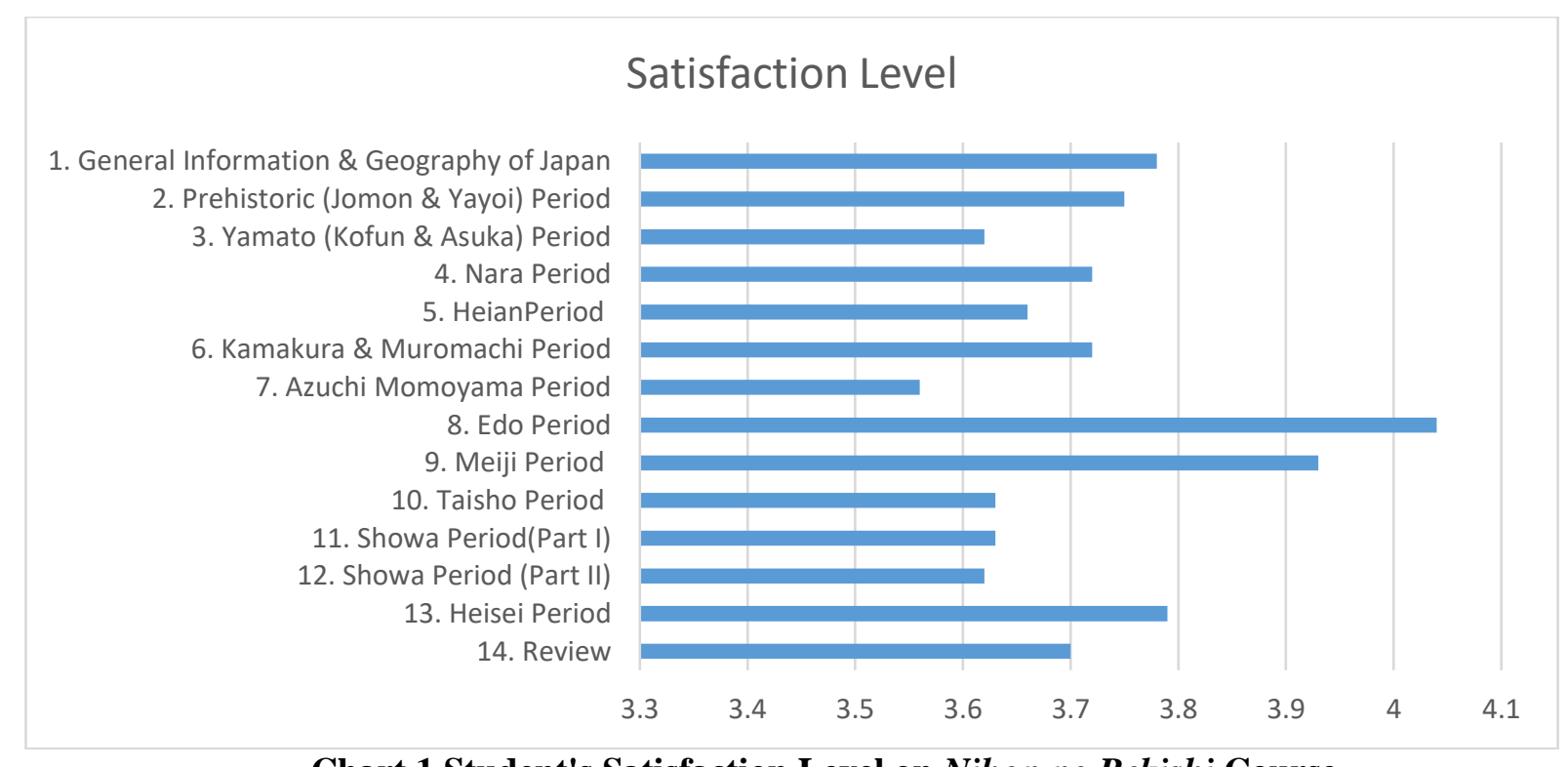

\section{Chart 1 Student's Satisfaction Level on Nihon no Rekishi Course}

In the odd semester of the 2019-2020 academic year, two courses have been carried out that discuss Japanese culture and society studies, namely Nihon no Rekishi for second semester and Nihon Gendaishi for the fourth semester. As an evaluation tool, the Nihon no Rekishi course compilation team has held survey through a questionnaire that has been distributed to students in the second and fourth semester who are taking Nihon no Rekishi lectures. The distribution of evaluation questionnaires was carried out from 6-23 January 2020. The collected data on the evaluation questionnaire for the Nihon no Rekishi course were 210 of 420 students in the third and fifth semester or as much as $50 \%$. This course is a course intended to introduce Japanese history to first-level Japanese language learners. The results of the questionnaire are presented in chart 1.

In chart 1, we could see the theme points taught in the Nihon no Rekishi course for first semester students in 13 meetings. The 
theme for Nihon no Rekishi are prepared so that students know basic things related to Japanese history which are presented per era from general information \& geography of Japan which is continued with the Jomon period to the Heisei period. Based on chart 1 , the most exciting theme for students is a theme about the Edo period with a scale of 4.04 (from a scale of 5). Meanwhile, the theme that students are less interested in is about Azuchi Momoyama period with a scale of 3.56 (from a scale of 5). The average level of satisfaction with the Nihon no Rekishi course is 3,72 points.

Chart 2 shows the number of respondents for each theme presented on what theme are of interest and benefit to students. The most exciting and useful theme chosen were general information \& geography of Japan as many as 117 people. In comparison, the least was material about the Azuchi Momoyama period as many as 26 people.

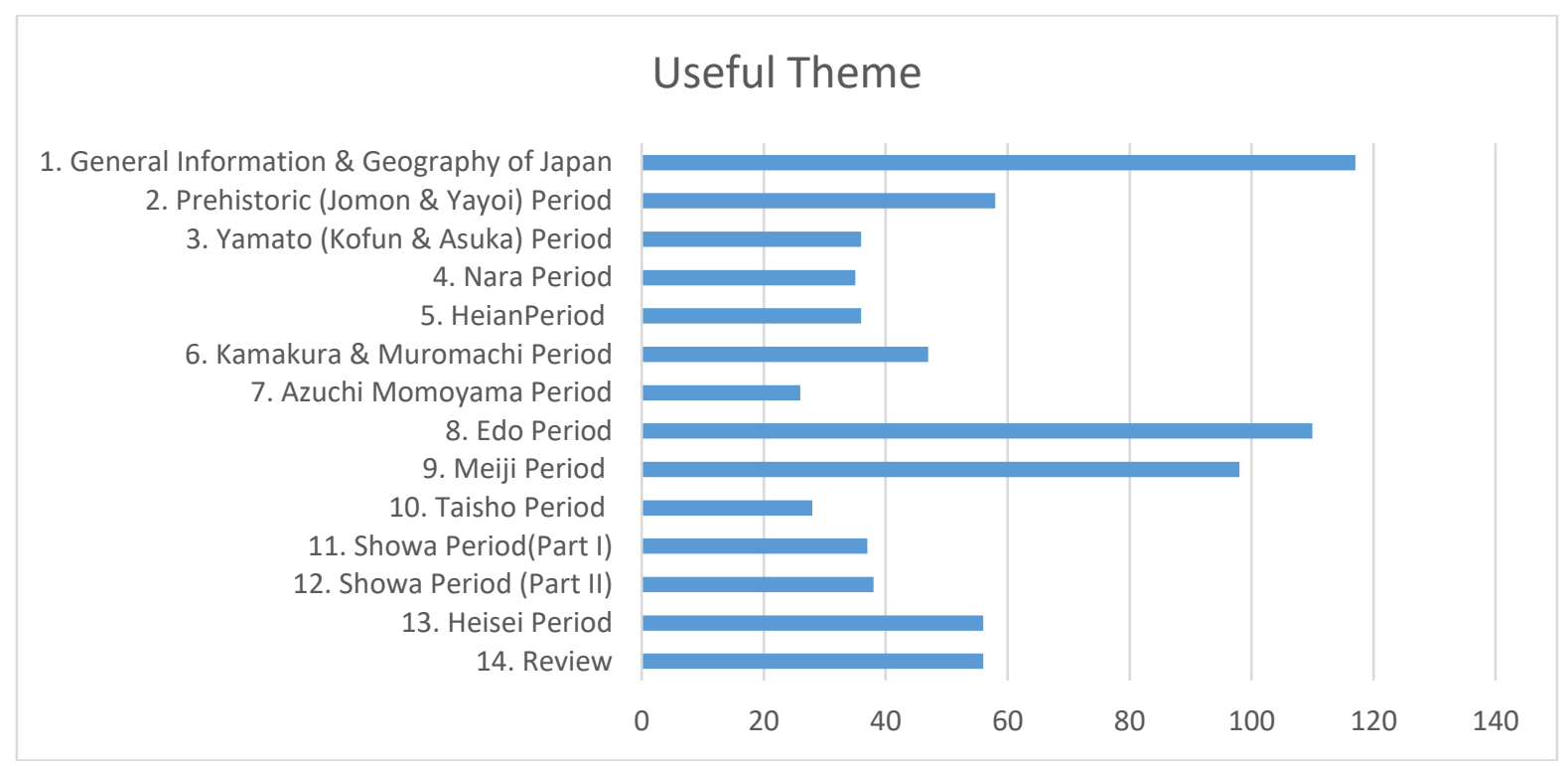

\section{Chart 2 Useful Theme}

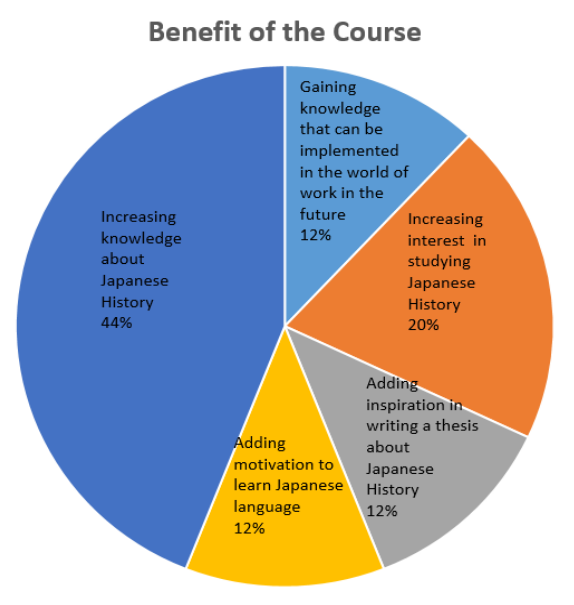

Chart 3 Benefit of the Course

The Nihon no Rekishi team provided options regarding some of the benefits that were obtained after taking the Nihon no

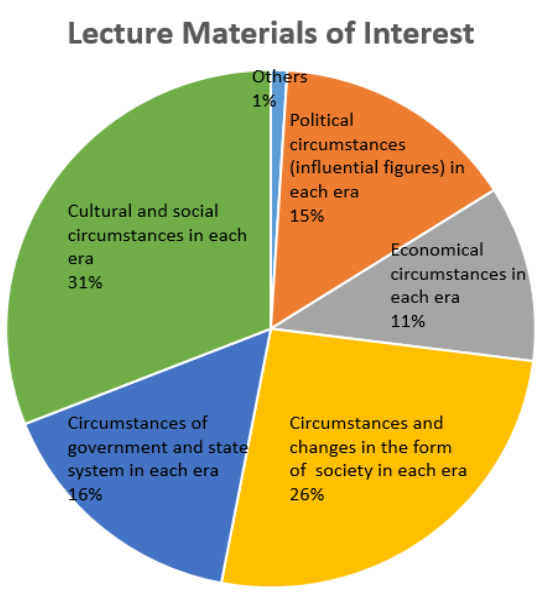

Chart 4 Lecture Materials of Interest

Rekishi course. The widest choice is increasing knowledge about Japanese history showing a percentage of $44 \%$, 
increasing interest in studying Japanese history, showing a percentage of $20 \%$. While other benefits such as getting knowledge that can be implemented in the world of work in the future, adding (increasing) motivation to learn Japanese language, and adding inspiration in writing a thesis about Japanese history each showing a percentage of $12 \%$.

Viewing from chart 4, the cultural and social conditions in each era are the most popular material, showing a percentage of $31 \%$. The cultural and social conditions are only introduced to each era's peculiarities. At the same time, a more in-depth discussion is studied in the Nihon Bunka Shakai Nyumon course which studies Japanese culture and society.

In chart 5, it is known that the use of audio-visual media (video) is the teaching method most desired by students, showing a percentage of $34 \%$. In comparison, the flipped class by providing material online by the lecturer then the students discuss in detail the following day showing the lowest percentage of $9 \%$. This percentage is the reason for researching module development and improvement, considering that teaching methods need special attention because students find it challenging to understand the modules used at that time. Seeing the usage of audio-visual media (video) ranks the highest in the type of teaching method, from this, it is evident that the modules used so far are problematic. Therefore, there is a need to carry out research, development and improvement of the existing modules.

Department of Japanese Language and Culture, Darma Persada University realises that students need knowledge and insight related to Japanese history to support Japanese language learning. These courses include Nihon no Rekishi (second semester) and Contemporary Japanese History (seventh semester).

Historical study is a reflection of past events. Darma Persada University Japanese Literature Department realises that students need knowledge and insight related to
Japanese history to support foreign language learning, mostly Japanese. So that the Nihon no Rekishi course for second-semester students and Contemporary Japanese History for seventh-semester students was implemented. Especially for other countries with the study of Japanese history are exist like Indonesia, especially in a smaller scope, academic community of the Darma Persada University is expected to learn from Japan's past experiences for the country's development in a better way.

We compile some teaching material, such as Sono Toki Nihon ga Tsukurareta (Nishiumi, 2007) highlight turning points in Japanese history, and while discussing this history, it explains the most significant events. Furthermore, it compares Japanese history with Western history and to arrange the logic itself in a way that is easy for students to understand. Besides, Pengantar Sejarah Jepang I (Surajaya, 1996) is roughly divided into two eras, namely the monarchy era and the feudal era. However, it is further divided into sub-ages which only lasted until the Edo period, and there is little explanation about the era after that. The weak point of this book is that there are no photos or pictures related to the material presented.

It is best combined with another source like Seikatsu Kaizen (Ong, 2017), that explained the history of Japanese modernisation, which began in the 1860 s. We should see what efforts have been made by the Japanese government and society, to succeed in realising a modern, prosperous and advanced country, with people who are disciplined, diligent, productive and have a sense of social responsibility. Shakai Kaizō (Ong, 2019) explained that the modernisation era in Germany and America is only about one generation apart compared to Japan. Responding to the negative impact of modernisation, academics and bureaucrats (and Christian religious leaders) in Germany and America immediately came up with ideas for improvement, which the Japanese also quickly absorbed and implemented. It caused Japan to be advanced and equal with 
Western countries. The readiness of the Japanese people to continuously learn from other developed countries in order to move forward is an attitude that our country should learn. Other sources that focus on contemporary Japanese history are Pengantar Sejarah Jepang II (Surajaya, 1997) that explained World War II was a real dividing line in Japanese history, and the reforms that followed have resulted in widespread social change in the country. Contemporary Japanese History (Vardaman \& Higuchi, 2013) that intended for a general reader to give an overview of the flow of Japanese history since 1945 . It tries to remain neutral and give consideration to reasonable differences of perspective on often contentious issues.

This research aims to convey information about learning conditions and student interest levels related to themes in Japanese history. Based on this information, the development of teaching methods and teaching materials based on the ADDIE method will be carried out.

\section{Methods}

Research methods is a scientific way of obtaining data for specific useful purposes. The scientific way means that research activities are based on characteristics scientific, namely rational, empirical, and systematic (Darmadi, 2013).

The research is literature research or 'desk research' which is included in qualitative research which is supported by the results of the analysis in the form of diagrams and charts to strengthen the results of the arguments. Moleong (2005) states that qualitative research is research that intends to understand the phenomena experienced by research subjects such as behaviour, perception, motivation, action, as a whole, and by describing it in the form of words and language, in a particular natural context and with make use of various scientific methods. This research is desk research using secondary data such as books, scientific journals, and articles related to the material that will be included in the learning module of the Nihon no Rekishi subject. The stages of this research include: 1) Determine the material points to be included in the Nihon no Rekishi course module; 2) Looking for references as secondary data by the points of learning material in the Nihon no Rekishi course; 3) Processing data and references to compile material according to the points of learning material for the Nihon no Rekishi course; 4) Compiling the entire learning material into a module for the Nihon no Rekishi course (second semester).

The research approach used in this learning model development research is the research and development approach ( $\mathrm{R} \&$ D). Educational research and development ( $\mathrm{R} \& \mathrm{D}$ ) is a process used to develop and validate educational products. The steps of this process are usually referred to R \& D cycle. It consists of studying research findings pertinent to the product to be developed, developing the product based on the finding, field testing it in the setting where it will be used eventually, and revising it to correct deficiencies found in the field testing stage. It is indicating that the product meets its behaviorally defined objectives (Borg \& Gall, 1983:772).

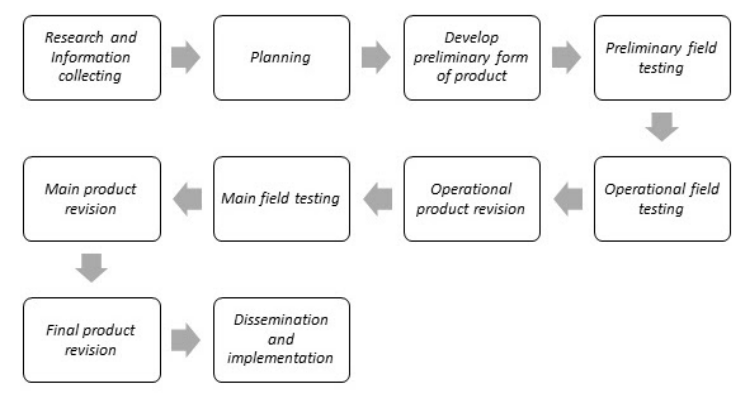

Source: https://rezarachmadtullah.wordpress.com/2018/08/16/pendekatan-research-and-development-r-d/

\section{Result and Discussion}

Gredler (1991) said that learning is one of the requirements for acquiring new knowledge in order to build an understanding of prior knowledge. Therefore, lecturers 
(teachers) are required to be able to provide the best method for achieving learning objectives. We are trying to apply a teachingmethod design called ADDIE, which helps to track how we measure efficiency the course, improve student's eagerness of the subject and develop the teaching materials.

The ADDIE model of instructional design is a generic instructional model that provides an organised process for developing instructional materials. This systemic model is a five-step cyclical process that can be used for both traditional and online instruction (Shelton et al., 2007).

First of all, there is 1) Analyse phase by student's feedback toward Nihon no Rekishi subject presented in charts. Next is 2) Design for the planning of teaching materials, competencies and teaching and learning methods, and it has already applied on last even semester AY 2019/2020. Now, we are already done the analyse stage and design stage, then 3) Development, the team, need taking consultation with Japanese History experts. About 4) Implement our team must screening and browsing Japan History short video from Youtube \& group discussion. Furthermore, the last is 5) Evaluation, we will evaluate teaching methods and materials for future perfection, and students participate in the evaluation process.

The results of chart 1 to 5 describe the contents of the questionnaire, which will be analysed in order to achieve a useful teaching module. First, it is seen from the material points taught in the Nihon no Rekishi course for second-semester students in 14 meetings. Nihon no Rekishi materials were prepared with the aim of students knowing basic things related to Japanese history which were presented with a focus on division per period from general information on the Japanese state which was continued with the Jomon period to the Heisei era. According to the students, the material that attracted them the most was the Edo period material with a scale of 4.04 . It has a difference of 0.48 from the Azuchi Momoyama era, which is less attractive to students with a scale of 3.56 (from a scale of 5).

Furthermore, from the presentation of the material, what material is exciting and useful for the student. The results of the questionnaire showed that the most chosen ones were regarding general information, the geographic layout of Japan as many as 117 people. In comparison, only 26 people chose material about the Azuchi Momoyama period which was the least exciting material. Responding to this, the Nihon no Rekishi research team provided an option on how useful the material obtained after attending the Nihon no Rekishi course. The most significant choice fell on the statement adding knowledge about Japanese history, which was $44 \%$. Meanwhile, other benefits such as: "getting knowledge that can be implemented in the world of work in the future", "increasing interest in studying Japanese history", and "increasing motivation to learn Japanese" had the same percentage at $12 \%$.

Next, from chart 4 , information related to cultural and social conditions in each era is the material most desirable to study in more detail, until it shows a percentage of $31 \%$. The teaching plan regarding the cultural and social conditions is only focused on introducing its distinctive points in each era. A more general discussion will be studied in the Nihon Bunka Shakai Nyumon course which studies Japanese culture and society to maintain the optimal process of knowledge transfer so that information is the same is not repeated in different courses.

The final discussion, namely, in chart 5 the team knows that the use of audio-visual media (video) as the most desirable teaching method, occupies a percentage of up to $34 \%$. In comparison, the flipped class by providing material online first by the lecturer, then the learners will discuss in detail at lecture days occupy a percentage of only $9 \%$. Seeing that the use of audio-visual media ranks highest in the type of teaching method, it is evident from this that the modules used so far have problems. Therefore, 
there is a need to carry out research, development and improvement of the existing modules. The reason for researching module development and improvement is more substantial, given that teaching methods are an aspect that must be considered because students find it challenging to understand the modules that are being used.

\section{Conclusion}

In the even semester of the AY 2018/2019, Darma Persada University used the book Ryūgakusei no tame no Nihonshi (Japanese History: An Introductory Text) as a lecture guide book. As the title implies, the book is intended for foreign (non-Japanese) students so that the Japanese language used is Japanese for foreign students. However, this book is deemed ineffective as lecture teaching material because students find it challenging to grasp the essence of the material and lectures are considered fixated on translation.

The purpose of this research is to publish quality modules as teaching materials and guidebooks for lecturers and students in the Nihon no Rekishi course, which is compiled based on the results of research \& Japanese historical studies. By the indicators contained in the problem formulation, the material to be included in the lecture module includes materials that introduce Japanese history from various aspects such as economy, politics, education, social, culture.

It is continued with the process of selecting literature references and compiling lecture material points as well as processing data and references to compile material following the points of learning material for the Nihon no Rekishi course in order to complete the process of developing module compilation. Compile the entire learning material into a module for the Nihon no Rekishi course (second semester).

This research on the usage of modules that have been developed will enter a trial stage of second-semester students of class 2020 in the even semester of the AY
2020/2021. Of course, there must be a stage of evaluating the effectiveness and improvement of the Nihon no Rekishi module in order to achieve the goals of students who are besides proficient in foreign languages but also understand the background of the country in which they are learning the language.

\section{References}

Borg, W. R., Gall, M. D., and Gall, J. P. (1989). Educational Research: An Introduction, Fifth Edition. New York: Longman.

Darmadi, Hamid. (2013). Metode Penelitian Pendidikan dan Sosial. Bandung: Alfabeta.

Gomi, F., \& Toriumi, Y. (2017) Shin Mou Ichido Yomu Yamakawa Nihonshi. Tokyo: Yamakawa Shuppansha

Gredler, Margareth E. Bell. (1991). Belajar dan Membelajarkan. Jakarta: Rajawali.

Kochhar, S.K. (2008). Pembelajaran Sejarah. Penerjemah Purwanta dan Yofita Hardiwati. Jakarta: Grasindo.

Moleong, Lexy J. (2005). Metodologi Penelitian Kualitatif. Jakarta: Rosda Karya

Nishiumi C., Takemori G. T. (2011) Sono Toki Nihon ga Tsukurareta. Tokyo: IBC Publishing.

Ong, Susy. (2017). Seikatsu Kaizen. Jakarta: Gramedia.

Ong, Susy. (2019). Shakai Kaizo. Jakarta: Gramedia.

Shelton, Kaye and Saltsman, George. (2007). Using the ADDIE Model for Teaching Online. Pennsylvania: Idea Group Publishing 
IZUMI, Volume 9 No 2, 2020, [Page | 208]

e-ISSN: 2502-3535, p-ISSN: 2338-249X

Available online at: http://ejournal.undip.ac.id/index.php/izumi

Surajaya, I Ketut. (1996). Pengantar Sejarah Jepang I. Depok: Universitas Indonesia

Surajaya, I Ketut. (1997). Pengantar Sejarah Jepang II. Depok: Universitas Indonesia

Tokyo University of Foreign Studies Center of International Students \& Educational Teaching Material Development. (1990). Ryūgakusei no Tame no Nihonshi (Japanese History: an Introductory Text). Tokyo: Yamakawa Shuppansha

Vardeman, J.M., Higuchi, K. (2013). Contemporary Japanese History: since 1945. Tokyo: IBC Publishing.
Wineburg, Sam. (2006). Berpikir Historis: Memetakan Masa Depan Mengajarkan Masa Lalu. Masri Maris (penerjemah). Jakarta: Yayasan Obor Indonesia.

Website:

https://www.colorado.edu/ptea-curriculum/imaging-japanese-history

https://langsquare.exblog.jp/20844310/ https://www.sal.tohoku.ac.jp/en/research/s pecializations/lab/---id-15.html

https://journal.unnes.ac.id/sju/index.php/ijh e/article/view/19918 